\title{
Regulation of insulin release in persistent hyperinsulinaemic hypoglycaemia of infancy studied in long-term culture of pancreatic tissue
}

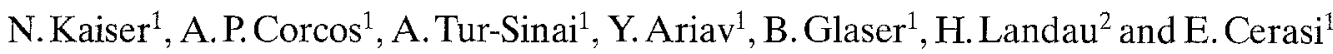 \\ Departments of ${ }^{1}$ Endocrinology and Metabolism and ${ }^{2}$ Pediatrics, Hebrew University Hadassah Medical Center, Jerusalem, Israel
}

\begin{abstract}
Summary. Pancreatic tissue was obtained during therapeutic subtotal pancreatectomy from five infants with persistent hyperinsulinaemic hypoglycaemia of infancy (socalled nesidioblastosis). Collagenase digests of the specimens were cultured in RPMI 1640 medium on extracellular matrix-coated plates. Acute insulin secretion showed minimal sensitivity to changes in glucose concentration. Sensitivity to other nutrient secretagogues such as glyceraldehyde, leucine, $\alpha$-ketoisocaproic acid and arginine was variable, showing either diminished or absent response. On the other hand, stimulators of Beta cell cAMP and modulators of the phosphoinositide-protein kinase $C$ pathway were effective inducers of insulin release. The response to cAMP stimulators was independent of the glucose concentration. Although insulin
\end{abstract}

output was high in the absence of glucose, this was not due to passive leak of hormone, since both removal of calcium and addition of somatostatin and epinephrine inhibited the secretion. Beta cells were more sensitive to somatostatin than epinephrine; however, both agents failed to completely suppress the release even at suprapharmacological concentrations. Although it cannot be excluded that the culture conditions affected Beta cell function, the present findings may suggest that cultured Beta cells in persistent hyperinsulinaemic hypoglycaemia of infancy behave like fetal Beta cells at early developmental stages.

Key words: Nesidioblastosis, hyperinsulinaemic hypoglycaemia, insulin release, islet culture, Beta cell maturation, hypoglycaemia.
Persistent hyperinsulinaemic hypoglycaemia of infancy (PHHI) is a rare condition of which the aetiology is not clear. A wide spectrum of pancreatic morphological features has been described; nesidioblastosis, initially thought to be the underlying cause, is common to all neonates and infants [1-5]. The nuclear volume of Beta cells is augmented $[1,5]$, but its significance in PHHI is unclear, since in accordance with observations in islets and in other endocrine cells [5-7] it may rather be the consequence of increased secretory activity.

The biochemical defect of the endocrine pancreas in PHHI is also unknown, and only few investigators have succeeded in studying islet function under controlled in vitro conditions [8,9]. Aynsley-Green et al. were successful in isolating islets from the pancreatic tissue of one out of three infants with PHHI; during short-term incubations they observed an abnormal Beta cell sensitivity to glucose, with maximal stimulation at $4 \mathrm{mmol} / \mathrm{l}$ glucose [9]. In the present study we utilized an improved method for islet cell culture in order to characterize Beta cell function in infants with PHHI. The method enables us to obtain monolayer cultures of pancreatic islets from adult rats in which Beta cells retain their differentiated function for several weeks in vitro [10]. In the present investigation we studied in some detail the regulation of insulin secretion by various physiological and pharmacological modulators using chronic cultures of pancreatic cells from infants with PHHI.

\section{Materials and methods}

Origin of tissue

Pancreatic tissue was obtained during therapeutic subtotal pancreatectomy from five infants suffering from intractable PHHI. The diagnosis of PHHI was based on the following criteria: spontaneous hypoglycaemia with inappropriately high plasma insulin levels; glucose requirement in excess of $15 \mathrm{mg} \cdot \mathrm{kg}^{-1} \cdot \mathrm{min}^{-1}$ in order to prevent hypoglycaemia; elevation of blood glucose by more than $1.67 \mathrm{mmol} / \mathrm{l}$ after glucagon administration; documentation of appropriate counterregulatory hormone responses; and low levels of non-esterified fatty acids and ketone bodies. All infants were delivered at term after a normal pregnancy. Their relevant clinical data is presented in Table 1. Pancreatic cultures A, B, C, D and E were from infants aged $26,10,6,9$ and 3.5 weeks, respectively, at the time of surgery. Tissue resected from the head and the tail of the pancreas was immediately placed into ice-cold sterile RPMI 1640 medium and transferred to the laboratory for further processing. 

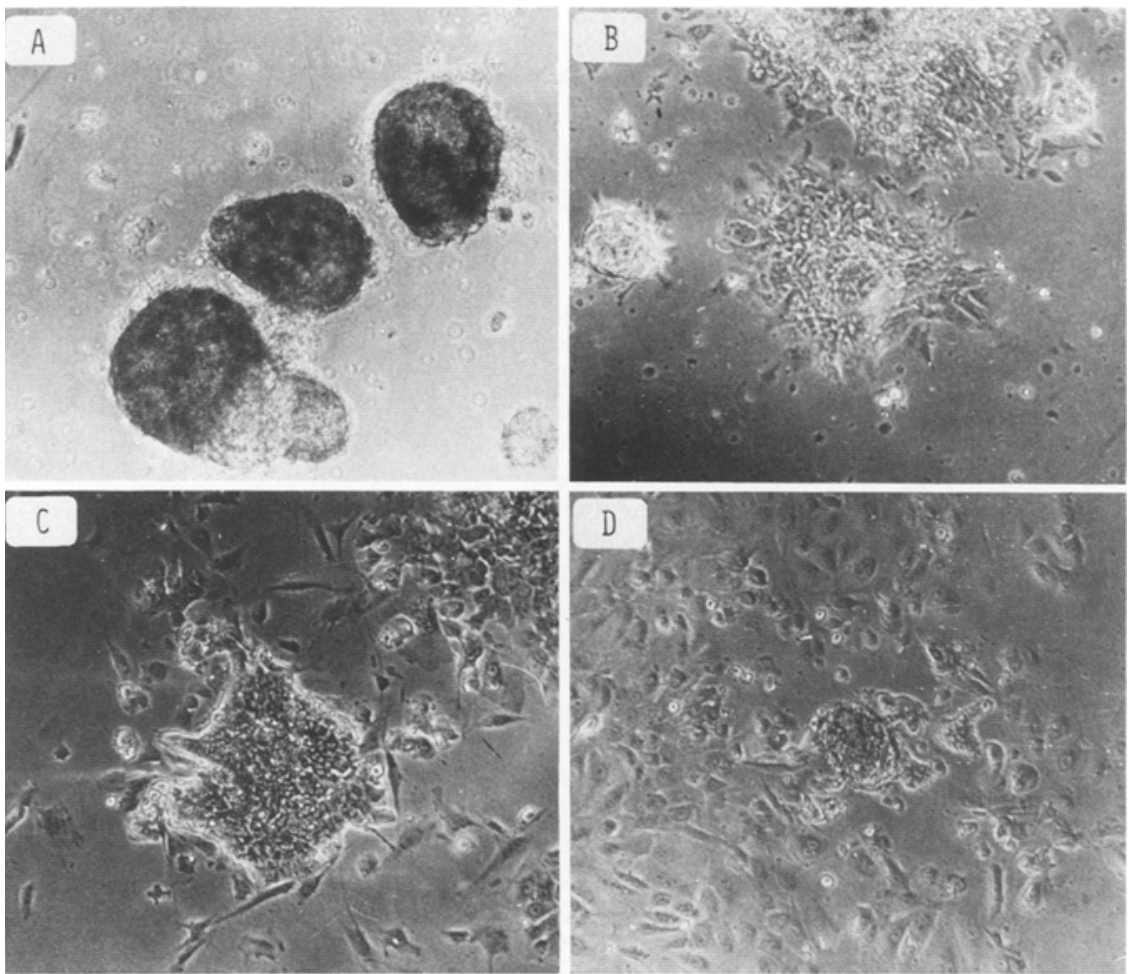

Fig. 1A-F. Cultures of pancreatic tissue from patients with persistent hyperinsulinaemic hypoglycaemia of infancy on extracellular matrix-coated plates. A Islet-like cell clusters after 1 day in culture. B 3-day-old culture. C 5-day-old culture. D 9-day-old culture. E 2-week-old primary culture showing a cluster of epithelial-like cells on top of a fibroblastoid cell layer. F An isolated group of epithelial cells forming a monolayer patch in a secondary culture (A-E, phase contrast $\times 100$; $\mathbf{F}$, phase contrast $\times 200)$
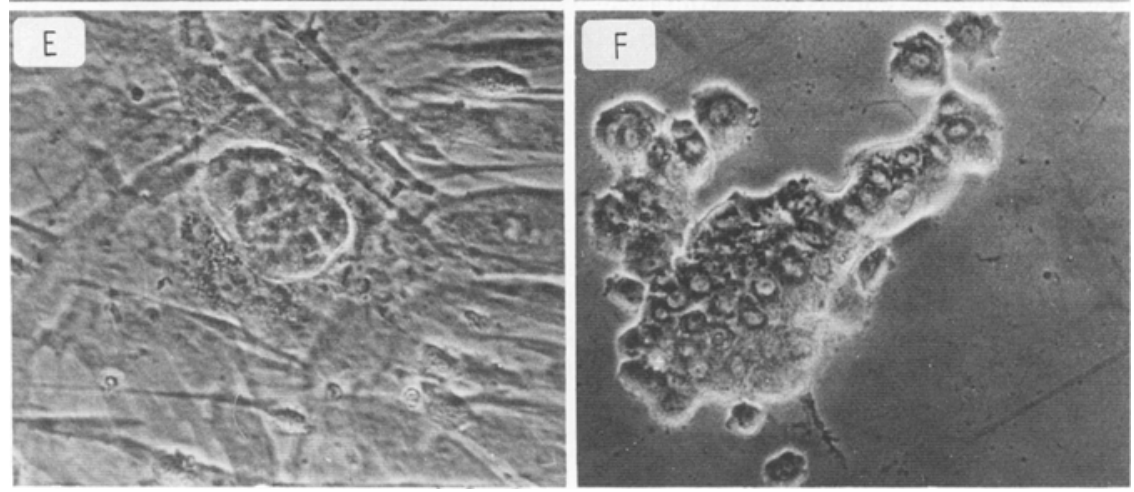

\section{Culture procedure}

Pancreatic tissue $(\sim 1 \mathrm{~g})$ was minced with scissors into $1-2 \mathrm{~mm}$ pieces which were digested by vigorous shaking at $37^{\circ} \mathrm{C}$ in $5 \mathrm{ml}$ Hepes-buffered (10 mmol/l) Hanks' balanced salt solution (HBSS), pH 7.4, containing $6 \mathrm{mg} / \mathrm{ml}$ collagenase $(0.94 \mathrm{U} / \mathrm{mg}$, Serva Feinbiochemica, Heidelberg, FRG). After 20-30 min the digest was diluted with an equal volume of cold HBSS, centrifuged, and washed four times with HBSS at $4^{\circ} \mathrm{C}$. Since only few opaque islet-like structures could be identified under the stereomicroscope, no attempt was made to isolate pure islets, and the whole digest was resuspended in RPMI 1640 medium (GIBCO, Grand Island, NY, USA) containing antibiotics $\left(10^{5} \mathrm{U} / \mathrm{l}\right.$ penicillin and $100 \mathrm{mg} / \mathrm{l}$ streptomycin). After three additional washes in this medium at room temperature, the pellet was resuspended in RPMI 1640 medium containing antibiotics and 10\% fetal calf serum (FCS, Biological Industries, Beth Haemek, Israel) at $37^{\circ} \mathrm{C}$. The digest of $1 \mathrm{~g}$ pancreatic tissue was suspended in $60 \mathrm{ml} \mathrm{cul}-$ ture medium and $2 \mathrm{ml}$ of this cell suspension plated into $35 \mathrm{~mm}$ Falcon culture dishes coated with extracellular matrix (ECM) derived from bovine corneal endothelial cells as described previously [ 10 , 11]. The cultures were maintained at $37^{\circ} \mathrm{C}$ under $6 \% \mathrm{CO}_{2}$ in air with twice weekly changes of the medium. Most studies were performed

Table 1. Patient clinical and laboratory data

\begin{tabular}{|c|c|c|c|c|c|c|c|c|c|}
\hline \multirow{2}{*}{$\begin{array}{l}\text { Patient } \\
\text { code }\end{array}$} & \multirow[t]{2}{*}{ Sex } & \multirow{2}{*}{$\begin{array}{l}\text { Family } \\
\text { history } \\
\text { of PHHI }\end{array}$} & \multicolumn{3}{|c|}{ Age (weeks) } & \multicolumn{4}{|c|}{ Spontaneous hypoglycaemia ${ }^{a}$} \\
\hline & & & Diagnosis & Admission $^{\mathrm{b}}$ & Surgery & $\begin{array}{l}\text { Glucose } \\
(\mathrm{mmol} / \mathrm{l})\end{array}$ & $\begin{array}{l}\text { Insulin } \\
(\mathrm{mU} / \mathrm{I})\end{array}$ & $\begin{array}{l}\text { Cortisol } \\
\text { (nmol/l) }\end{array}$ & $\begin{array}{l}\text { Growth } \\
\text { hormone }(\mu \mathrm{g} / \mathrm{l})\end{array}$ \\
\hline $\bar{A}$ & Female & Positive & 2 & 20 & 26 & 1.1 & 17 & 552 & 14 \\
\hline $\mathrm{C}$ & Male & Positive & Birth & 1 & 6 & 1.2 & 21 & 662 & 15 \\
\hline $\mathrm{D}$ & Male & Positive & Birth & 0.5 & 9 & 3.6 & 113 & 524 & 12 \\
\hline$E$ & Female & Positive & Birth & 0.5 & 3.5 & 2.4 & 33 & 331 & 10 \\
\hline
\end{tabular}

a Glucose and insulin were assayed in the same plasma sample. Cortisol and growth hormone were from other episodes of hypoglycaemia (glucose less than $2.3 \mathrm{mmol} / \mathrm{l}$ ); ${ }^{\mathrm{b}}$ Age of admission at this hospital. PHHI = persistent hyperinsulinaemic hypoglycaemia of infancy 
with primary cultures. In some experiments secondary cultures were obtained from pancreatic cultures $\mathrm{B}$ and $\mathrm{D}$ by mild trypsin digestion and replating on new ECM-coated dishes; results were essentially similar in primary and secondary cultures.

\section{Study of hormone content and release}

The culture medium was changed $16-24 \mathrm{~h}$ before each experiment and collected to determine chronic insulin secretion. At the start of experiments RPMI 1640 medium was replaced by $1 \mathrm{ml}$ KrebsRinger bicarbonate buffer, $\mathrm{pH} 7.4$, containing $10 \mathrm{mmol} / 1$ Hepes, $0.25 \% \mathrm{BSA}$ (KRBH buffer) and 0 or $3.3 \mathrm{mmol} / \mathrm{l}$ glucose. The cultures were preincubated in this buffer for $1 \mathrm{~h}$ at $37^{\circ} \mathrm{C}$, then the buffer was discarded, and the cultures were incubated in $1 \mathrm{ml}$ of the same buffer for another $\mathrm{h}$ to give the $1 \mathrm{st} \mathrm{h}$ insulin secretion rate. Thereafter, buffers containing various concentrations of glucose with or without other agents were added and the incubation continued for a further $\mathrm{h}$ (2nd $\mathrm{h}$ of incubation). The incubation buffers were stored at $-20^{\circ} \mathrm{C}$ for insulin assay. In some experiments after glucose stimulation, the cultures were extracted for $24 \mathrm{~h}$ at $4^{\circ} \mathrm{C}$ with acid-ethanol (15 $\mathrm{ml} 12 \mathrm{~mol} / 1 \mathrm{HCl}$ of $70 \%$ ethanol) for determination of cell insulin. content. Insulin was measured by radioimmunoassay, using guineapig anti-porcine insulin antibodies (Linco Research Inc., Eureka, Mo, USA) and a second antibody to separate bound and free hormone. Human insulin (Novo Research Institute, Bagsvaerd, Denmark) was used as a standard. The minimal detectable concentration was $0.7 \pm 0.06 \mathrm{mU} / 1$. Intraassay coefficient of variance $(\mathrm{CV})$ was less than $6 \%$ across the entire range of the assay, while interassay $\mathrm{CV}$ was $13 \%, 9.7 \%$ and $10 \%$ at insulin concentrations of 7,23 , and $83 \mathrm{mU} / 1$, respectively.

\section{Datapresentation}

Since results could not be related to Beta cell number or protein content in these mixed cell cultures, and insulin secretion rates were variable, each plate was subjected to consecutive treatments with glucose and other test compounds, the insulin secretion rate during the $2 \mathrm{nd} \mathrm{h}$ calculated as \%, or fold increase, of the 1 st h of incubation, and results were grouped and normalized to untreated control.

\section{Statistical analysis}

Data were computed as mean \pm SEM and compared using the nonparametric Mann-Whitney $U$ test. When data obtained at different glucose concentrations were pooled, e.g. when studying the effect of cAMP modulators on insulin secretion, we used the Kruskal-Wallis one-way analysis of variance to test the effect of ambient glucose concentration.

\section{Results}

Monolayer cultures composed of a mixed cell population were obtained from all pancreatic specimens. During the 1st day of culture, islet-like cell clusters of irregular shape were seen, which within several hours attached to the ECM-coated plates (Fig. 1 A). After 3 days, most of the cell clusters were flattened; the cultures contained epitheliallike cells, together with fibroblastoid cells and binucleated cells, the latter probably of exocrine origin (Fig.1B). On the 5th day of culture discrete patches of epithelial-like cells were apparent (centre of Fig. 1C). The appearance of the culture did not change much over the next few days

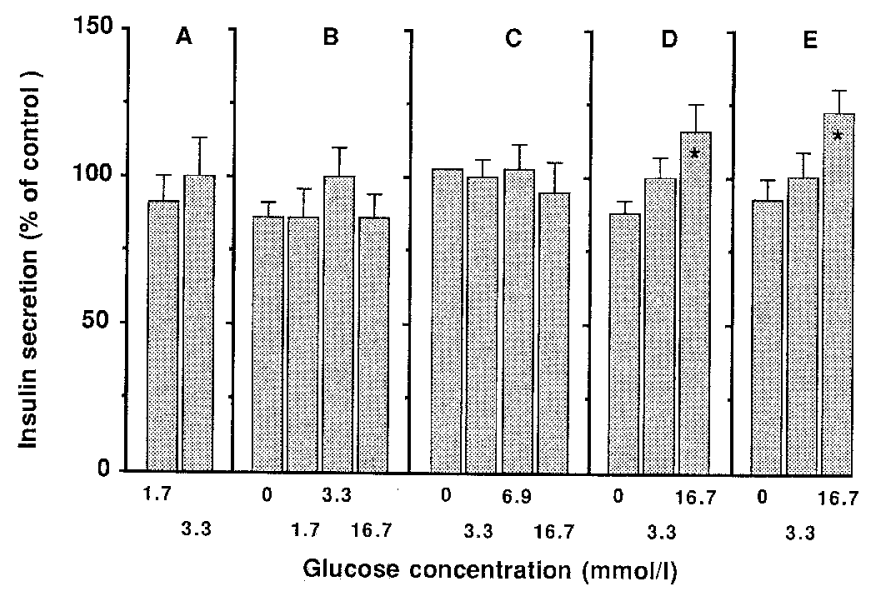

Fig. 2A-E. Effect of glucose on insulin release in cultured pancreatic tissue from infants with persistent hyperinsulinaemic hypoglycaemia of infancy. All cultures (1-4 week old) were incubated for $1 \mathrm{~h}$ in glucose-free Krebs-Ringer bicarbonate-Hepes buffer, except for culture $\mathrm{C}$ which was at $3.3 \mathrm{mmol} / \mathrm{l}$. During the following h the cultures were exposed to varying glucose concentrations as indicated in the Figure. Insulin secretion during the second $h$ was calculated as $\%$ of insulin output during the $1 \mathrm{st} h$ and normalized to control incubations which contained the basal glucose concentration of $3.3 \mathrm{mmol} / \mathrm{l}$ during the $2 \mathrm{nd} h$ of incubation. Results are shown as mean \pm SEM of 3-17 plates. Asterisk indicates $p<0.05$ or less compared to results at 0 glucose

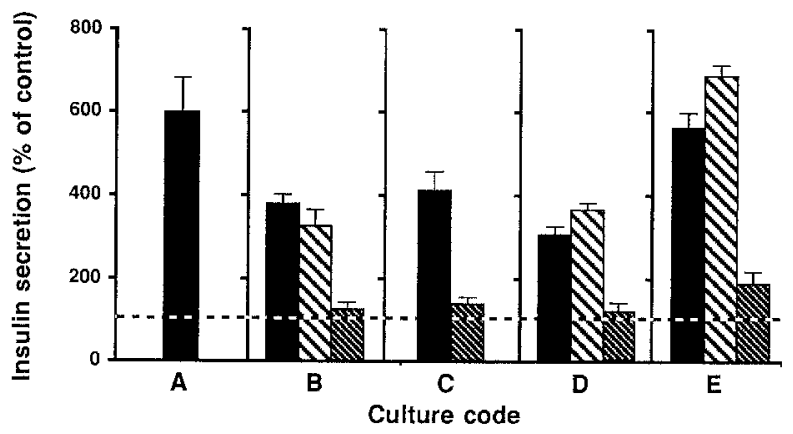

Fig.3A-E. Effect of modulators of cAMP on insulin secretion. Cultures were incubated for $1 \mathrm{~h}$ in glucose-free Krebs-Ringer bicarbonate-Hepes buffer or in buffer containing up to $16.7 \mathrm{mmol} / 1$ glucose. During the 2 nd h of incubation, cultures were exposed to buffer containing varying concentrations of glucose $(0-16.7 \mathrm{mmol} / 1)$ with or without 3-isobutyl-1-methylxanthine (IBMX) $(0.1 \mathrm{mmol} / \mathrm{l}$, black column), forskolin ( $25 \mu \mathrm{mol} / \mathrm{l}$, hatched column) and glucagon ( $30 \mathrm{nmol} / \mathrm{l}$, grey column). Insulin secretion during the second $\mathrm{h}$ of incubation with and without the cAMP modulators was calculated as \% of 1st hinsulin output. Results obtained at different concentrations of glucose were pooled for each modulator, since by Kruskal-Wallisanalysis of variance glucose was not found to affect islet response to the modulators. Pooled results were normalized to modulator-free controls (taken as $100 \%$, dashed line) and presented for each culture as mean \pm SEM of 3-24 plates. $p$ values, calculated relative to control cultures by the Mann-Whitney U test, were $<0.002$ for IBMX and $<0.005$ for forskolin in all cultures tested. Glucagon caused a significant increase in insulin secretion $(p<0.05)$ only in cultures $\mathbf{B}, \mathbf{C}$ and $\mathbf{E}$

(Fig. 1D); however, after 2 weeks in culture (Fig. 1E), the fibroblastoid cells grew over the endocrine cells, the latter appearing as isolated clusters on top of a fibroblast layer. The binucleated cells were nolonger present. Subculture of the cells by mild trypsin digestion and plating on new ECMcoated plates, followed by thimerosal treatment to elimi- 


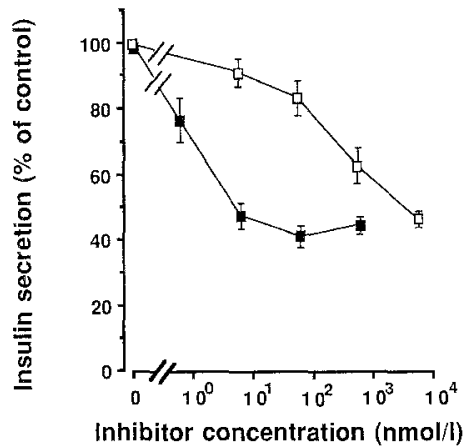

Fig. 4. Dose-response curve for the effect of epinephrine and somatostatin on insulin secretion. One to 4-week-old cultures of pancreatic tissue from patients $\mathrm{B}, \mathrm{C}, \mathrm{D}$ and $\mathrm{E}$ were incubated for two consecutive hours: first in presence of $3.3 \mathrm{mmol} / \mathrm{l}$ glucose in KrebsRinger bicarbonate-Hepes buffer, followed by a 2 nd $\mathrm{h}$ in the same buffer with and without epinephrine (open squares) or somatostatin (black squares). Insulin secretion during the 2 nd $\mathrm{h}$ of incubation relative to the 1 st $\mathrm{h}$ in control cultures containing glucose alone, is taken as reference $(100 \%)$ for the effect of the inhibitors. Symbols and vertical lines denote mean \pm SEM of 5-15 plates

nate fibroblasts [10], resulted in secondary cultures which contained reduced numbers of epithelial-like endocrine cells with little fibroblast contamination (Fig.1F). However, due to excessive loss of viable cells, this procedure was abandoned, most studies being performed in primary cul- tures. The cultures of patients $A$ and $B$ survived for 8 weeks after which insulin secretion disappeared and all cells became fibroblastoid. The cultures of patients $\mathrm{C}, \mathrm{D}$ and $E$ were lost after 2,4 and 3 weeks, respectively, by bacterial contamination due to the repetitive use of the plates.

Chronic insulin secretion was evaluated by measuring the accumulation of insulin in the RPMI 1640 medium (11.1 mmol/l glucose) 16-24 h after medium change. Very high levels were observed on day 4, which gradually decreased during the first week of culture. Most of our studies were performed in 1-4 week-old cultures. During this period islet function was stable, and no effect of culture time on chronic or acutely stimulated insulin secretion was observed.

The $24 \mathrm{~h}$ insulin secretion was $95 \pm 12 \%$ and $102 \pm 29 \%(n=3)$ of tissue insulin content in cultures D and $\mathrm{E}$, respectively, while a secretion rate of $16 \pm 2 \%$ $(n=6)$ of content was found in cultures exposed to glucose-free KRBH buffer for $1 \mathrm{~h}$.

The viability of Beta cells was tested at various times during culture using $0.1 \mathrm{mmol} / 1$ 3-isobutyl-1-methylxanthine (IBMX), or $25 \mu \mathrm{mol} / \mathrm{l}$ forskolin; cells were considered viable if they increased their insulin output by at least 1.5 fold. By this criterion, viable Beta cells were still present in some of the mixed cell cultures even after 8 weeks ( 6 out of 9 cultures responded to forskolin with $2-3$ fold increase in insulin secretion).

Table 2. Effect of nutrients on insulin secretion in cultured pancreatic tissue from infants with PHHI

\begin{tabular}{|c|c|c|c|c|c|c|}
\hline Nutrient & $\begin{array}{l}\text { Glucose } \\
\text { during } \\
\text { incubation } \\
(\mathrm{mmol} / \mathrm{l})\end{array}$ & $\begin{array}{l}\text { Insulin secretion } \\
\text { during } 1 \text { st } h \\
\left(\mu \mathrm{U} \cdot \text { plate }^{-1} \cdot \mathrm{h}^{-1}\right)\end{array}$ & $\begin{array}{l}\text { Insulin secretion } \\
\text { during } 2 \mathrm{nd} \mathrm{h}^{\mathrm{h}} \\
\left(\mu \mathrm{U} \cdot \text { plate }^{-1} \cdot \mathrm{h}^{-1}\right)\end{array}$ & $\begin{array}{l}\text { Stimulation }{ }^{\mathrm{a}} \\
\text { factor }\end{array}$ & $n$ & $p \leq^{b}$ \\
\hline Control & 0 & $69 \pm 6$ & $48 \pm 4$ & 1.00 & 17 & \\
\hline Control & 3.3 & $27 \pm 11$ & $22 \pm 9$ & 1.00 & 4 & \\
\hline Glyceraldehyde & 0 & $76 \pm 22$ & $60 \pm 19$ & $1.10 \pm 0.03$ & 3 & NS \\
\hline Arginine & 3.3 & $28 \pm 9$ & $23 \pm 9$ & $0.97 \pm 0.08$ & 3 & NS \\
\hline \multicolumn{7}{|l|}{ Culture C } \\
\hline Control & 3.3 & $245 \pm 33$ & $186 \pm 28$ & 1.00 & 9 & \\
\hline Arginine & 3.3 & $146 \pm 44$ & $133 \pm 31$ & $1.3 \pm 0.22$ & 3 & NS \\
\hline \multicolumn{7}{|l|}{ Culture D } \\
\hline \multicolumn{7}{|l|}{ Culture E } \\
\hline Control & 0 & $202 \pm 48$ & $144 \pm 29$ & 1.00 & 10 & \\
\hline Control & 3.3 & $124 \pm 17$ & $131 \pm 21$ & 1.00 & 11 & \\
\hline Glyceraldehyde & 0 & $33 \pm 9$ & $56 \pm 19$ & $2.09 \pm 0.13$ & 3 & 0.01 \\
\hline Glyceraldehyde & 3.3 & $116 \pm 11$ & $237 \pm 35$ & $1.94 \pm 0.13$ & 3 & 0.005 \\
\hline Leucine & 3.3 & $102 \pm 9$ & $149 \pm 12$ & $1.40 \pm 0.04$ & 3 & 0.01 \\
\hline $\mathrm{KIC}$ & 0 & $28 ; 39$ & $33 ; 64$ & $1.49 ; 2.08$ & 2 & \\
\hline $\mathrm{KIC}$ & 3.3 & $161 \pm 27$ & $248 \pm 19$ & $1.62 \pm 0.17$ & 6 & 0.001 \\
\hline Arginine & 3.3 & $100 \pm 9$ & $192 \pm 21$ & $1.85 \pm 0.06$ & 3 & 0.005 \\
\hline
\end{tabular}

Cultures were incubated in buffer containing either no glucose or $3.3 \mathrm{mmol} / \mathrm{l}$ glucose for $1 \mathrm{~h}$ followed by a 2 nd h of incubation in the same buffer with no additives (control) or with the indicated nutrients each at $10 \mathrm{mmol} / \mathrm{l}$. Results are expressed as mean $\pm \mathrm{SEM}$.

${ }^{a}$ Stimulation factor is computed for individual plates by calculating the ratio between 2 nd and 1 st $h$ insulin secretion; the values were then normalized in relation to control incubations (assigned a factor of 1.00). ${ }^{b} p$ values are calculated relative to their respective controls using the Mann-Whitney U test. " KIC: $\alpha$-ketoisocaproic acid, PHHI = persistent hyperinsulinaemic hypoglycaemia of infancy 
Table 3. Effect of modulators of phosphoinositide metabolism and TPA on insulin secretion in cultured pancreatic tissue from infants with PHHI

\begin{tabular}{|c|c|c|c|c|c|}
\hline Treatment & $\begin{array}{l}\text { Insulin secretion } \\
\text { during } 1 \mathrm{st} h \\
\left(\mu \mathrm{h} \cdot \text { plate }^{-1} \cdot \mathrm{h}^{-1}\right)\end{array}$ & $\begin{array}{l}\text { Insulin secretion } \\
\text { during } 2 \mathrm{nd} \mathrm{h}^{\mathrm{h}} \\
\left(\mu \mathrm{U} \cdot \text { plate }^{-1} \cdot \mathrm{h}^{-1}\right)\end{array}$ & $\begin{array}{l}\text { Stimulation } \\
\text { factor }\end{array}$ & $n$ & $p \leq$ \\
\hline \multicolumn{6}{|l|}{ Culture D } \\
\hline $\begin{array}{l}\text { Control } \\
\text { TPA }(10 \mathrm{nmol} / \mathrm{l}) \\
\text { Carbachol }(10 \mu \mathrm{mol} / 1) \\
\text { MOG }(100 \mu \mathrm{mol} / 1) \\
\text { Carbachol }(10 \mu \mathrm{mol} / 1) \\
+ \text { MOG }(100 \mu \mathrm{mol} / 1)\end{array}$ & $\begin{array}{l}94 \pm 13 \\
96 \pm 8 \\
86 \pm 20 \\
91 \pm 19 \\
132 \pm 9\end{array}$ & $\begin{array}{r}99 \pm 16 \\
292 \pm 56 \\
138 \pm 19 \\
82 \pm 18 \\
189 \pm 25\end{array}$ & $\begin{array}{l}1.00 \\
2.96 \pm 0.57 \\
1.61 \pm 0.17 \\
0.87 \pm 0.01 \\
1.38 \pm 0.16\end{array}$ & $\begin{array}{r}16 \\
3 \\
3 \\
4 \\
4\end{array}$ & $\begin{array}{l}0.01 \\
0.01 \\
\text { NS } \\
0.02\end{array}$ \\
\hline \multicolumn{6}{|l|}{ Culture E } \\
\hline $\begin{array}{l}\text { Control } \\
\text { TPA }(10 \mathrm{nmol} / \mathrm{l}) \\
\text { Carbachol }(10 \mu \mathrm{mol} / \mathrm{l}) \\
\text { MOG }(100 \mu \mathrm{mol} / \mathrm{l}) \\
\text { Carbachol }(10 \mu \mathrm{mol} / \mathrm{l}) \\
+ \text { MOG }(100 \mu \mathrm{mol} / \mathrm{l})\end{array}$ & $\begin{array}{l}124 \pm 17 \\
95 \pm 11 \\
24 \pm 5 \\
107 \pm 22 \\
64 \pm 6\end{array}$ & $\begin{array}{r}131 \pm 21 \\
574 \pm 76 \\
72 \pm 13 \\
97 \pm 20 \\
232 \pm 54\end{array}$ & $\begin{array}{l}1.00 \\
5.96 \pm 1.15 \\
2.88 \pm 0.13 \\
0.89 \pm 0.17 \\
3.40 \pm 0.42\end{array}$ & $\begin{array}{r}11 \\
3 \\
3 \\
3 \\
3\end{array}$ & $\begin{array}{l}0.005 \\
0.005 \\
\text { NS } \\
0.005\end{array}$ \\
\hline
\end{tabular}

The ability of Beta cells to respond acutely to glucose was assessed in all cultures. As seen in Figure 2, increasing glucose concentration from $0 \mathrm{mmol} / 1$ during the $1 \mathrm{st} \mathrm{h}$ of incubation to $1.7-16.7 \mathrm{mmol} / \mathrm{l}$ during the following $\mathrm{h}$ had little effect on insulin release; only cultures D and E responded with a $\sim 30 \%$ increase. In light of this observation we tested cultures $\mathrm{D}$ and $\mathrm{E}$ for their ability to stop insulin output upon reduction of the glucose concentration from 16.7 to $0 \mathrm{mmol} / \mathrm{l}$. Inspite of the small Beta-cell response to an increase in medium glucose, the cultures failed to respond to its omission ( $1 \mathrm{~h}$ incubations; data not shown).

The failure of the cultures to respond to an acute glucose stimulus prompted us to study their ability to react to other nutrients (Table 2). Exposure to substrate secretagogues at either 0 or $3.3 \mathrm{mmol} / 1$ glucose evoked variable responses. While cultures $\mathrm{B}$ and $\mathrm{C}$ showed no secretory response to the tested nutrients, cultures $\mathrm{D}$ and $\mathrm{E}$ increased insulin secretion 1.3-2 fold in response to glyceraldehyde, leucine, $\alpha$-ketoisocaproic acid and arginine.

The response of the cultures to pharmacological and physiological modulators of cAMP is shown in Figure 3. Both IBMX and forskolin were effective in augmenting insulin secretion, irrespective of the medium glucose concentration. Glucagon caused only a modest stimulatory effect in three out of four tested cultures ( 27 to $88 \%$ above control).

Table 3 shows the effects of carbachol, a muscarinic cholinergic agonist which stimulates phospholipid breakdown in normal islets [12], 1-monooleoyl-rac-glycerol (MOG), an inhibitor of diacylglycerol kinase [13], and 12O-tetradecanoylphorbol 13-acetate (TPA), an activator of protein kinase C. TPA and carbachol, but not MOG, stimulated insulin release when tested at $3.3 \mathrm{mmol} / \mathrm{l}$ glucose, culture $\mathrm{E}$ being more responsive than culture $\mathrm{D}$ to these agents.

Calcium, a major regulator of insulin secretion in normal islets, was important also for insulin release from
Table 4. Effect of calcium withdrawal on insulin secretion in cultured pancreatic tissue from infants with PHHI

\begin{tabular}{|c|c|c|c|c|}
\hline $\begin{array}{l}\text { Incubation } \\
\text { conditions }\end{array}$ & $\begin{array}{l}\text { Glucose } \\
\text { concentration } \\
(\mathrm{mmol} / \mathrm{l})\end{array}$ & $\begin{array}{l}\text { Insulin secretion } \\
\left(\mu \mathrm{U} / \text { plate }^{-1} \cdot \mathrm{h}^{-1}\right)\end{array}$ & $\Delta \%^{\mathrm{a}}$ & $p \leq^{\mathrm{b}}$ \\
\hline \multicolumn{5}{|l|}{ Culture B } \\
\hline $\begin{array}{l}\text { Control } \\
\text { Ca-free }\end{array}$ & $\begin{array}{l}0 \\
0\end{array}$ & $\begin{array}{l}58 \pm 14(3) \\
11 \pm 2(3)\end{array}$ & -81 & 0.01 \\
\hline $\begin{array}{l}\text { Control } \\
\text { Ca-free }\end{array}$ & $\begin{array}{l}3.3 \\
3.3\end{array}$ & $\begin{array}{c}77 \pm 42(3) \\
8 \pm 2(3)\end{array}$ & -89.7 & 0.05 \\
\hline \multicolumn{5}{|l|}{ Culture D } \\
\hline $\begin{array}{l}\text { Control } \\
\text { Ca-free }\end{array}$ & $\begin{array}{l}3.3 \\
3.3\end{array}$ & $\begin{array}{l}94 \pm 15(18) \\
17 \pm 2(9)\end{array}$ & -81.9 & 0.001 \\
\hline \multicolumn{5}{|l|}{ Culture E } \\
\hline $\begin{array}{l}\text { Control } \\
\text { Ca-free }\end{array}$ & $\begin{array}{l}0 \\
0\end{array}$ & $\begin{array}{c}240 \pm 13(4) \\
27 \pm 4(4)\end{array}$ & -88.8 & 0.01 \\
\hline $\begin{array}{l}\text { Control } \\
\text { Ca-free }\end{array}$ & $\begin{array}{l}3.3 \\
3.3\end{array}$ & $\begin{array}{c}152 \pm 22(4) \\
16 ; 22(2)\end{array}$ & -87.5 & 0.05 \\
\hline $\begin{array}{l}\text { Control } \\
\text { Ca-free }\end{array}$ & $\begin{array}{l}16.7 \\
16.7\end{array}$ & $\begin{array}{c}331 \pm 32(4) \\
74 \pm 9(3)\end{array}$ & -77.6 & 0.02 \\
\hline
\end{tabular}

Cultures were incubated in Krebs-Ringer bicarbonate-Hepes (KRBH) buffer modified as indicated in the Table. Ca-free buffer also contained $5 \mathrm{mmol} / \mathrm{l}$ EGTA. Insulin secretion during $1 \mathrm{~h}$ of incubation is expressed as mean \pm SEM. The number of plates is in parenthesis.

a \% change relative to control cells in regular KRBH buffer containing the same concentration of glucose. ${ }^{\mathrm{b}} p$ values are calculated relative to their respective controls using the Mann-Whitney $U$ test. PHHI = persistent hyperinsulinaemic hypoglycaemia of infancy

PHHI pancreatic cultures (Table 4). Omission of calcium reduced insulin secretion by $\sim 85 \%$. This effect of calciumfree medium was observed both in the presence and $a b$ sence of glucose.

Epinephrine and somatostatin (Fig. 4) elicited a dosedependent suppression of insulin secretion in all tested 
cultures. Maximal inhibitory response $(40 \%$ of untreated control culture) was obtained with $6 \mathrm{nmol} / 1$ somatostatin, whereas epinephrine caused a similar effect only at $5500 \mathrm{nmol} / \mathrm{l}$. While full dose response curves were conducted only in the presence of $3.3 \mathrm{mmol} / \mathrm{lglucose}$, the pancreatic tissue of patient $B$ was also exposed to the inhibitors under glucose-free conditions. In the absence of glucose, epinephrine $(5500 \mathrm{nmol} / \mathrm{l})$ and somatostatin $(600 \mathrm{nmol} / \mathrm{l})$ reduced the output of insulin by $58 \pm 10 \%$ and $32 \pm 1 \%(n=3)$, respectively.

\section{Discussion}

Over the past decade 28 patients with PHHI have been studied in our medical centre [14]. It became possible to study the in vitro islet function in this disorder only recently by the development of improved islet cell culture techniques. Indeed, by using ECM-coated plates as a support surface, we have been able to culture rat islets with maintenance of normal Beta cell function for periods longer than 2 months [10]. This report represents our initial efforts to characterize Beta cell function, using the above technique, in the last five patients with PHHI to undergo subtotal pancreatectomy. In contrast to rat or adult human pancreas, and in accordance with the experience of Aynsley-Green et al. [9], only a small number of islets could be isolated from the pancreas of PHHI patients by collagenase digestion; we therefore cultured the entire pancreatic digest. While this technique permitted us to use repeatedly the same plates for functional studies and thus compensated for the scarcity of tissue, we could not prevent the overgrowth of fibroblasts which precluded studying the biochemical characteristics of these islet cells. In several studies with adult and fetal human islets, elevation of Beta cell cAMP was shown to be the most effective stimulus of insulin secretion [15-18]. Using IBMX or forskolin we monitored the presence of Beta cells in our cultures. By this criterion, viable Beta cells were present for as long as 8 weeks in culture; this is similar to our experience with rat pancreatic Beta cells cultured on ECM-coated plates [10].

The salient feature of insulin release in our study is the deficient response to changes in ambient glucose concentration. Similar glucose unresponsiveness is typical of the human fetal pancreas at its early stages of development $[16$, $18,19]$. In freshly incubated islets of a PHHI patient, Aynsley-Green et al. [9] found an abnormal sensitivity to glucose, with maximal stimulation of insulin release at $4 \mathrm{mmol} / \mathrm{l}$. It is not clear to us if this difference from our observations is due to the techniques used, or whether it reflects a characteristic of the one patient studied by Aynsley-Green et al. In the present studies, in addition to absent or limited responses to raised glucose levels, the omission of glucose failed to reduce the secretion. This too is similar to findings in perifused islet-like cell clusters from pancreases of human fetuses at 17-20 weeks of gestation which, although showing a $\sim 1.6$ fold increase in insulin secretion, did not shut off the release when the glucose concentration was reduced from 20 to $2 \mathrm{mmol} / \mathrm{l}$ [18]. The response to other nutrient secretagogues was variable with some of the cultures showing a modest response. Also in vivo some PHHI patients showed sensitivity to leucine and arginine $[9,20]$. Thus, some heterogeneity exists regarding the extent of nutrient non-recognition by these Beta cells.

Insulin secretion in pancreatic cultures of PHHI is a regulated function despite the lack of sensitivity to nutrients. Indeed, agents that augment Beta cellc AMPstimulated insulin release in a manner quantitatively similar to the response of normal islets $[10,21,22]$. The insulinotropic effect of IBMX, forskolin and glucagon was independent of ambient glucose. Also, human fetal islets respond to agents elevating intracellular cAMP in the absence of glucose [17], thus differing from the response of adult rat islets [23]. Insulin secretion could also be stimulated in PHHI cultures via the phosphoinositide-protein kinase $C$ pathway, since both carbachol and TPA effectively increased hormone release. The diacylglycerol kinase inhibitor MOG was inactive by itself and did not potentiate the effect of carbachol. The significance of this observation is not clear to us.

The insulin secretory characteristics of PHHI discussed so far could indicate that in this disorder the normal maturation process that allows the full expression of substrate sensitivity in the Beta cell is deficient. However, these patients suffer from hypoglycaemia, i. e. inability to suppress insulin secretion when blood glucose falls below baseline. In agreement with the clinical picture, the insulin release rate in our cultures was not reduced in the total absence of glucose. However, insulin release is not caused by leakage from the Beta cell, since removal of calcium from the incubation medium reduced markedly the release. Thus, exocytosis appears to characterize secretion also in these Beta cells, which respond normally to the two physiologic regulators (calcium and cAMP) of insulin release. Another finding which may be of clinical significance was that even at high pharmacologic concentrations both somatostatin and epinephrine failed to abolish the insulin secretion. The sensitivity of the cultured Beta cells to somatostatin was several orders of magnitude greater than to epinephrine. This in vitro finding is of interest since some PHHI patients respond well to the administration of somatostatin or its analogues [24-27], while the endogenous catecholamine response to hypoglycaemia fails to suppress insulin release.

An additional finding that may be related to the intractable hypoglycaemia of PHHI is the high turnover rate of insulin observed in our cultures. Indeed, $16 \%$ of cell content of insulin was secreted during $1 \mathrm{~h}$ in glucosefree medium, compared to $1.2 \pm 0.1 \%(n=16)$ in adult rat islets cultured similarly on ECM-coated plates (unpublished observation). Others have shown a similar low turnover rate in cultured fetal and adult human islets [28, 29] and in suspended adult human islets [30]. Thus, PHHI Beta cells seem to show an insulinoma-like high rate of release of their insulin content.

In summary, our data suggest that in PHHI the Beta cells resemble cells in the early fetal pancreas by their defective recognition of nutrient secretagogues and lack of glucose dependency of their cAMP mediated insulin release $[16,19]$. On the other hand, the substantial reduction of insulin release obtained with hormonal inhibitors (somatostatin and epinephrine) or with removal of calcium ions in the absence of glucose may suggest that even without substrate these Beta cells are in a "stimulated" state. 
Some caution is however necessary for the interpretation of these results. Indeed, although long-term cultures on ECM have been shown not to modify the responsiveness of rat islets [10], pancreases from healthy infants have not been tested in this system. Thus, an artefact that may induce nutrient unresponsiveness selectively in infant but not rat Beta cells cannot be excluded. Further studies, including culture of islet cells from normoglycaemic infants, will be necessary to validate the conclusions of the present investigation in relation to the aetiology of PHHI.

Acknowledgments. The authors are grateful to Ms. D.Zemach for insulin determinations and to Ms. L. Granot for typing the manuscript. This work was supported by grants from the Wolfson Foundation, the George Grandis Endowment for Medical Research and the Fund for Basic Research Administered by the Israel Academy of Sciences and Humanities. A.P.Corcos was a recipient of a Juvenile Diabetes Foundation International Scholarship.

\section{References}

1. Jaffe R, Hashida Y, Yunis EJ (1980) Pancreatic pathology in hyperinsulinemic hypoglycemia of infancy. Lab Invest 42: 356 365

2. Rahier J, Wallon J, Henquin JC (1981) Cell populations in the endocrine pancreas of human neonates and infants. Diabetologia 20: $540-546$

3. Yakovac WC, Baker L, Hunmeler K (1971) Beta cell nesidioblastosis in idiopathic hypoglycemia of infancy. J Pediatr 79: 226-231

4. Bishop AE, Polak JM, Chesa PG, Timson CM, Bryant MG, Bloom SR (1981) Decreased pancreatic somatostatin in neonatal nesidioblastosis. Diabetes 30: 122-126

5. Rahier J, Fält K, Müntefering H, Becker K, Gepts W, Falkmer S (1984) The basic structural lesion of persistent neonatal hypoglycaemia with hyperinsulinism: deficiency of pancreatic $\mathrm{D}$ cells or hyperactivity of $\mathbf{B}$ cells? Diabetologia 26: 282-289

6. Hellman B, Hellerström C (1959) Size differences of the B-cell nuclei in the islet tissue of normal and alloxan-treated rats. Acta Pathol Microbiol Scand 45: 113-122

7. Rahier J (1989) Relevance of endocrine pancreas nesidioblastosis to hyperinsulinemic hypoglycemia. Diabetes Care 12: 164166

8. Hollande E, Girron B, Lehy T, Accary JP, Rose C (1976) In vitro secretion of gastrin, insulin, and glucagon in tissue cultures of pancreas from a child with neonatal intractable hypoglycemia. Gastroenterology 71: 255-262

9. Aynsley-Green A, Polak JM, Bloom SR, Gough MH, Keeling J, Ashcroft SJH, Turner RC, Baum JD (1981) Nesidioblastosis of the pancreas: definition of the syndrome and management of the severe neonatal hyperinsulinaemic hypoglycaemia. Arch Dis Child 56: 496-508

10. Kaiser N, Corcos AP, Tur-Sinai A, Ariav Y, Cerasi E (1988) Monolayer culture of adult rat pancreatic islets on extracellular matrix: long term maintenance of differentiated B-cell function. Endocrinology 123: 834-840

11. Gospodarowicz D, Mescher AL, Birdwall CR (1977) Stimulation of corneal endothelial cell proliferation in vitro by fibroblast and epidermal growth factors. Exp Eye Res 25: 75-87

12. Best L, Malaisse WJ (1984) Nutrient and hormone-neurotransmitter stimuli induce hydrolysis of phosphoinositides in rat pancreatic islets. Endocrinology 115: 1814-1820

13. Bishop WR, Ganong BR, Bell RM (1986) Attenuation of sn-1,2diacylglycerol second messengers by diacylglycerol kinase. J Biol Chem 261: 6993-7000

14. Landau H, Glaser B, Hirsch HJ, Schiller M, Gross V, Corcos AP, Kaiser N, Cerasi E (1988) Persistent hyperinsulinemic hypoglycemia in infancy - long-term experience with 28 patients.
European Society of Pediatric Endocrinology, 27th Annual Meeting, Copenhagen (Abstract)

15. Nielsen JH, Brunstedt J, Andersson A, Frimodt-Moller C(1979) Preservation of beta cell function in adult human pancreatic islets for several months in vitro. Diabetologia 16: 97-100

16. Hoffman L, Mandel TE, Carter WM, Koulmanda M, Martin FIR (1982) Insulin secretion by fetal human pancreas in organ culture. Diabetologia 23: 426-430

17. Otonkoski T (1988) Insulin and glucagon secretory response to arginine, glucagon, and theophylline during perifusion of human fetal islet-like cell clusters. J Clin Endocrinol Metab 67: 734-740

18. Otonkoski T, Andersson S, Knip M, Simell O (1988) Maturation of insulin response to glucose during human fetal and neonatal development. Studies with perifusion of pancreatic islet-like cell clusters. Diabetes 37: 286-291

19. Tuch BE, Jones A, Turtle JR (1985) Maturation of the response of human fetal pancreatic explants to glucose. Diabetologia 28: 28-31

20. Schwartz SS, Rich BH, Lucky AW, Straus FH, Gonen B, Wolfsdord J, Thorp FW, Burrington JD, Madden JD, Rubenstein AH, Rosenfield RL (1979) Familial nesidioblastosis: severe neonatal hypoglycemia in two families. J Pediatrics $95: 44-53$

21. Grill V, Cerasi E (1974) Stimulation by D-glucose of cyclic adenosine $3^{\prime}: 5^{\prime}$-monophosphate accumulation and insulin release in isolated pancreatic islets of the rat. J Biol Chem 13:41964201

22. Wiedenkeller E, Sharp GWG (1983) Effects of forskolin on insulin release and cyclic AMP content in pancreatic islets. Endocrinology 113: 2311-2313

23. Brisson GR, Malaisse-Lagae F, Malaisse WJ (1972) The stimulus secretion coupling of glucose-induced insulin release. VII. A proposed site of action for adenosine-3' $5^{\prime}$-cyclic monophosphate. J Clin Invest 51: 232-241

24. Baker L, Stanley CA (1977) Hyperinsulinism in infancy: a pathophysiologic approach to diagnosis and treatment. In: Chiumello $G$, Laron $Z$ (eds) Recent progress in pediatric endocrinology. Academic Press, London, pp 89-100

25. Landau H, Perlaman M, Meyer S, Isacsohn M, Krausz M, Mayan H, Lijovetzky G, Schiller M (1982) Persistent neonatal hypoglycemia due to hyperinsulinism: medical aspects. Pediatrics 70 : $440-446$

26. Hirsch HJ, Loo S, Evans N, Crigler JF Jr, Filler RM, Gabbay KH (1977) Hypoglycemia of infancy and nesidioblastosis: studies with somatostatin. N Engl J Med 296: 1323-1326

27. Glaser B, Landau H, Smilovici A, Nesher R (1989) Persistent hyperinsulinaemic hypoglycaemia of infancy: long-term treatment with the somatostatin analogue Sandostatin. Clin Endocrinol 31: $71-80$

28. Kawazu S, Kanazawa Y, Hayashi M, Ikeuchi M, Nakai T, Kosaka K (1979) Monolayer culture of human fetal and adult pancreases. Static and dynamic studies of insulin release in vitro. Horm Metab Res 12: 354-360

29. Maitland JE, Parry DG, Turtle JR (1980) Perifusion and culture of human fetal pancreas. Diabetes 29 [Suppl 1]: 57-63

30. Andersson A, Borg H, Groth CG, Gunnarsson R, Hellerström C, Lundgren G, Westman J, Östman J (1976) Survival of isolated human islets of Langerhans maintained in tissue culture. J Clin Invest 57: 1295-1301

Received: 3 January 1990

and in revised form: 27 February 1990

\section{Dr. N. Kaiser}

Department of Endocrinology and Metabolism

Hadassah University Hospital

P.O.Box 12000

91120 Jerusalem

Israel 